\title{
The Relation between the Empowerment of Teacher's Meeting and Achievement Motivation on Teacher Performances in MTsN 3 (Islamic Junior High School 3) Simalungun
}

\author{
Sumiati Lince Saragih ${ }^{1}$, Rusydi Ananda ${ }^{2}$ \\ ${ }^{1}$ Teacher in MTsN 3 Simalungun, Indonesia \\ ${ }^{2}$ Lecturer of Masters Program in Tarbiyah and Teacher Training Faculty at UINSU Medan, Indonesia \\ rusdiananda.1972@gmail.com
}

\begin{abstract}
This study deals with The Relation between the Discussion Empowerments of Teacher and Achievements Motivation on Teacher Performances in MTsn (Islamic Junior High School) 3 Simalungun. This study is conducted by using descriptive qualitative design which used the correlational research method. The results shows that there are three positives and significances of each variables. 1) There is relationship between MGMP empowerment and teacher performance. It means that the higher and positive the MGMP empowerment, the higher and positive the teacher's performance by providing an effective contribution of $13.82 \%$. 2) There is also a positive and significant relationship between achievement motivation and teacher performance. It means that the higher and positive achievement motivation is the higher and positive the teacher's performance by making an effective contribution of $8.74 \%$. 3) There is a positive and significant relationship together between MGMP empowerment and achievement motivation with teacher performance. It means that the higher and positive MGMP empowerment and achievement motivation, the higher and positive the teacher's performance by making an effective contribution of $22.60 \%$.
\end{abstract}

Keywords : Empowerment of Teacher's Meeting, Achievement Needs, Teacher Performances.

\section{Introduction}

Teacher performance is the implementation of a plan that has been prepared through planning good learning activities that is by completing learning tools in the form of syllabus and learning implementation plans (RPP) instead planning poor learning activities if the teacher does not prepare learning tools in the form of syllabus and lesson plans. Implementation of performance is carried out by human resources who have the ability, competence, motivation, and interests. How madrasas respect and treat their human resources will influence their attitudes and behavior in carrying out performance.

However, there are teachers, who basically do not have deep and basic desires to teach. The work environment is also often the reason for teachers not to do much for madrassas. Poor communication, so the leader in giving assignments, which is done by the teacher does not have a clear purpose. There is no responsibility entrusted to the teacher. Often this is the trigger for the teacher to do nothing. There is no appreciation received for the achievements that have been achieved. All of the above relate to teacher performance. Thus the atmosphere of the madrasa becomes a motivator (motivation) for a teacher to improve the quality of his work.

When teachers experience problems and obstacles in terms of teaching, often the teacher does not have a place to discuss and give input on what is being faced. Then the role of other teachers is very decisive in terms of the teacher's desire to do the best, thus the role of the teacher's forum / scientific container will be a trigger for low or no teacher performance.

The right forum to answer the teacher's problems in teaching is subject teacher discussion. Activities originating from one cluster of fields of study were conducted to discuss 
the problems related to the field of study. Therefore, subject matter teacher discussion is one of the teacher upgrading systems with patterns from, by and for teachers.

Subject teacher meetings are formed starting from the madrasah, cluster, district, and provincial levels. Through subject teacher discussions, ongoing interactions occur between subject teachers in terms of fostering the enthusiasm of teachers to improve their abilities and skills in preparing, implementing and evaluating teaching and learning activities.

Subject teacher meetings, this becomes a forum for teachers to improve the skills of teachers in carrying out teaching, there is a discussion space that takes place to exchange ideas about the right methods, learning materials, and the right approach to learning. By means of a subject teacher consultation forum it is expected that teachers can maintain the quality of their performance in carrying out their duties as teachers according to the needs of the community, especially in the world of work.

The role of subject matter teacher participation in the process of improving performance, it is required to always make various breakthroughs which in the future will build quality education. Quality education will have high selling points. So that the implementation of subject teacher consultations has a very strategic role in efforts to improve teacher performance.

In order for the subject teacher discussion activities to be useful and can run as expected, the members should be involved at each stage of the organization's activities such as the program planning, implementation, and evaluation stages. However, the results of the study show that the teachers are basically only involved and involved optimally at the stage of the implementation of subject matter teacher discussion activities only. There are not many teachers involved in the planning stage such as in program preparation and schedule setting. It appears that the role of the board is more dominant and the preparation of this program is also not done through analysis of teacher needs. The same is true in the evaluation phase, where the teacher is only the object of evaluation, namely the person being evaluated.

\section{Review of Literatures}

\subsection{Teacher Performance}

Performance in English is called performance, which can be interpreted by: (1) work; deed or (2) appearance. Performance has a broader meaning, not just expressing it as a result of work, but how the work process takes place.

Performance is about doing work and the results achieved from the job. Performance is about what is done and how to do it. Performance is the result of work that has a strong relationship with the organization's strategic goals, customer satisfaction and economic contribution (Wibowo, 2007: 5).

Meanwhile performance according to Yuniarsih and Suwatno (2008: 161) is a real achievement that is displayed by someone after the person in charge of carrying out their duties and roles in the organization. This is similar to what was stated by Wibowo (2007: 7) that performance is the result of work that has a strong relationship with the organization's strategic goals, customer satisfaction and economic contribution. 
Simple definition expressed by Ivancevich, et al (2007: 216) that performance is the desired result of behavior. But perhaps the behavior intended by Ivancevich, et al has a very broad scope, namely concerning all individual activities in carrying out the tasks entrusted by the organization to him.

In line with their opinion Kirkpatrick and Nixon as quoted by Sagala (2007: 180) interpret performance as a measure of success in achieving goals that have been set or previously planned.

When connected with the teacher, the teacher's performance is nothing but the result of the desired performance from the teacher in the context of carrying out their duties. The main task of teachers in schools is to carry out teaching to students. Teaching is about teaching planning, implementation and evaluation of learning outcomes (planning, actuating, evaluation). Thus the teacher's performance is the performance in managing learning, which includes planning learning, implementing learning, and evaluating learning (Yuniarsih \& Suwatno, 2008: 153).

\subsection{Empowerment of Teacher's Meeting}

Empowerment is a translation of the word "empowering" which means developing human and other material resources. Empowering means encouraging becoming more involved in decisions and activities that affect individual work.

Robbin as quoted by Wibowo (2007: 112) describes empowerment as placing individuals accountable for what they do. The same thing was expressed by Greenberg and Baron in Wibowo (2007: 112) explaining that empowerment is a process in which individuals are given an increase in a number of autonomy and flexibility in relation to their work.

Tjiptono and Diana (2000: 128) define empowerment as involving individuals who really mean (significant). Meanwhile Newstrom and Davis in Wibowo (2007: 113) explain that empowerment is every process that gives greater autonomy to individuals through exchanging relevant information and provisions on supervision over factors that influence work performance.

Based on the explanation above, it can be interpreted that empowerment is a process to become individuals who are more empowered or more capable of completing their work by providing trust and authority so as to foster a sense of responsibility.

In this research study empowerment is intended to empower subject matter teachers at the madrasa level. This program has long been applied in an effort to equalize the ability of teachers in each subject in delivering learning material to students. Subject teacher meetings are a forum for meeting school subject teachers, this institution is non-structural but has a tiered structure starting from the provincial, district / city, sub-district to school level (Yunusshofa, 2008: 2).

This subject teacher meeting is an association used by teachers to solve all problems in the teaching and learning process in schools. MGMP functions as a means to communicate with each other, learn and exchange ideas and experiences in order to improve teacher performance as a practitioner / behavior changes in the reorientation of learning in the classroom. 
The role of teacher meeting forums in these subject teacher consultations is very strategic because it is used as a means to improve teacher competence and teacher performance. Deliberation of subject teachers carried out with more direction can be used as a vehicle for the development of quality, independent, and sustainable teacher professionalism (Ministry of National Education, 2009: 2).

This is in line with what was stated by Syafaruddin (2008: 141) which emphasizes that the teacher group in each school, such as subject teacher discussion is an important vehicle in empowering teachers, especially in improving the quality of teaching and learning. From the various opinions above, it is important for education providers, educators, and supervisors to pay attention to the continuity of the implementation of subject matter teacher consultations in each madrasa unit or at a higher level.

\subsection{Achievement Motivation}

Motivation in English called "motivation" comes from the Latin word "movere" which means to move (move or push). Lunenberg and Ornstein, as cited by Kamars (2005: 148), suggest that "motivation has been as" those processes within an individual that stimulate behavior and channel it in ways that should benefit the organization as a whole ". This means that motivation is a process in a person to stimulate behavior and channel it in ways that provide benefits to the organization as a whole. The notion that was introduced by Lunenberg and Ornstein is an understanding that leads to motivation that is in a person when in an organization, as an employee/ labor.

In line with that Usman (2008: 245), revealed that motivation is the desire to do something, while the motive is the need (need), desire (wish), encouragement (desire) or implus. So motivation is a desire found in someone to take actions or something that is the basis or reason for someone behaving. When connected with work, work motivation is nothing but the desires or needs that lie behind a person so that he is motivated to work.

Achievement according to Luthans (2006: 274) is the rate at which people hope to complete challenging goals, succeed in competition, and show a desire for clear feedback related to performance. From this definition, achievement motivation is nothing but the desire of someone to complete a job that is challenging and successful in every competition faced. This is in line with what was stated by Usman (2008: 259) that achievement motivation is an internal drive to overcome all obstacles and challenges in an effort to achieve goals.

One of the motives related to a person's behavior in an organization that is approached by psychologists according to Kamars (2005: 175) is beprestasi motivation (achievement needs). This motivation can cause an organization including educational institutions such as schools to have selling points and be able to compete with other superior schools in producing students.

Achievement motivation according to Robbins (2007: 222) is an encouragement to excel, to excel based on a set of standards, to strive for success. Robbins further stated that there are people who have a very strong urge to succeed. They wrestle for personal achievement rather than solely for the success rewards. They have a desire to do things better or more efficiently than they have done before. That encouragement is the need for achievement.

If the concept is applied to the teacher, the teacher's achievement motivation will result in the teacher's desire to always improve all the shortcomings he has in terms of carrying out 
tasks, especially teaching. If one method fails, the teacher continues to have the desire to find a more appropriate method or approach to learning so that students become more successful. From research on the need for achievements, Robbins (2008: 223) McClelland found that high achievers distinguish themselves from others based on their desire to accomplish what is done in a better way.

\section{Research Methods}

The study was conducted at MTsN 3 (Islamic Junior High School 3) Simalungun. This location was chosen considering that there had not been any research in the madrasa previously related to the title of this thesis research. The time of the study was conducted in the odd semester of the 2018-2019 academic year.

This research is quantitative research with correlation research methods, with the aim of describing three things, namely:

a. To find out the relationship between the variables of empowerment of subject teacher discussion (X1) with the performance variables of MTsN 3 (Islamic Junior High School 3) Simalungun.

b. To find out the relationship between achievement motivation variables of teachers in MTsN 3 (Islamic Junior High School 3) Simalungun (X2) with the performance variables of teachers at MTsN 3 (Islamic Junior High School 3) Simalungun (Y).

c. To find out the relationship between the variables of empowerment of subject teacher discussion (X1) and achievement motivation variables of teachers of MTsN 3 (Islamic Junior High School 3) Simalungun (X2) with the performance variables of teachers at MTsN 3 (Islamic Junior High School 3) Simalungun (Y).

The population included in this study were all 54 teacher of MTsN 3 (Islamic Junior High School 3) Simalungun with details as follows:

Table 3.2 Research Population

\begin{tabular}{|c|c|c|}
\hline No. & Teacher & Total Number of Teachers \\
\hline 1. & Government employees & 43 \\
\hline 2. & Honorer & 11 \\
\hline \multicolumn{2}{|c|}{ Total } & $\mathbf{5 4}$ \\
\hline
\end{tabular}

Because the number of population is not too much, the whole population is used as sample research, thus the sampling technique is done by means of total sampling (Arikunto, 2005: 87). Thus the sample of this study was 54 teachers.

\section{Discussion}

The results of data processing show that for the variable empowerment of subject teacher discussion has an average value or mean $=117.64$; mode $=117.14$; median $=117.77$; variance $=100.34 ;$ standard deviation $=10.01 ;$ maximum score $=135 ;$ and minimum score $=86$. 
The description of the frequency distribution of variable data empowering subject teacher consultations is presented in Table 4.1.

Table 4.1 Distribution of Variable Data for MGMP Empowerment

\begin{tabular}{|c|c|c|}
\hline Interval Class & $\mathrm{f}_{\text {absolute }}$ & $\mathrm{f}_{\text {relative }}(\%)$ \\
\hline $86-92$ & 1 & 1,85 \\
\hline $93-99$ & 1 & 1,85 \\
\hline $100-106$ & 5 & 9,26 \\
\hline $107-113$ & 9 & 16,67 \\
\hline $114-120$ & 18 & 33,33 \\
\hline $121-127$ & 10 & 18,52 \\
\hline $128-134$ & 9 & 16,67 \\
\hline $135-141$ & 1 & 1,85 \\
\hline Total & 54 & 100 \\
\hline
\end{tabular}

Based on the data in Table 4.1, it can be explained that the variable empowering subject teacher discussion with an average (mean) of 117.64 is in the interval class 114-120, this means that there are $33.33 \%$ of respondents in the class average score, $29,63 \%$ below the class average score and $37.04 \%$ above the class average score.

The results of data processing of achievement motivation variables of MTsN 3 (Islamic Junior High School 3) Simalungun show an average value or mean = 115.92; mode = 114.44; median $=115.83 ;$ variance $=56.67 ;$ standard deviation $=7.52 ;$ maximum score $=130 ;$ and minimum score $=98$.

Furthermore, the data distribution of achievement motivation variables for teachers in Simalungun State Madrasah Tsanawiyah 33 is presented in Table 4.3. as follows:

Table 4.2 Variable Data Distribution for Motivation Achievement

\begin{tabular}{|c|c|c|}
\hline Interval Class & $\mathrm{f}_{\text {absolute }}$ & $\mathrm{f}_{\text {relative }}(\%)$ \\
\hline $98-102$ & 3 & 5,56 \\
\hline $103-107$ & 4 & 7,41 \\
\hline $108-112$ & 8 & 14,81 \\
\hline $113-117$ & 18 & 33,33 \\
\hline $118-122$ & 11 & 20,37 \\
\hline $123-127$ & 6 & 11,11 \\
\hline $128-132$ & 4 & 7,41 \\
\hline Total & 54 & 100 \\
\hline
\end{tabular}


Based on the data in Table 4.3, it can be explained that the achievement motivation variables of MTsN 3 (Islamic Junior High School 3) Simalungun with a mean of 115.92 are in the interval class $113-117$, this means there are $33.33 \%$ of respondents in the class average score, $27.78 \%$ below the class average score and $38.89 \%$ above the class average score.

The results of data processing of teacher performance variables Simalungun Madrasah Tsanawiyah Negeri 3 shows an average value or mean $=112.94$; mode $=112.1$; median $=$ 113.1; variance $=66.43$; standard deviation $=8.15$; maximum score $=128$; and minimum score $=94$.

Furthermore, the variable distribution of performance data for teachers in Simalungun State Madrasah Tsanawiyah 3 is presented in Table 4.3.

Table 4.3 Variable Data Distribution of Teacher Performance

\begin{tabular}{|c|c|c|}
\hline Interval Class & $\mathrm{f}_{\text {absolute }}$ & $\mathrm{f}_{\text {relative }}(\%)$ \\
\hline $94-98$ & 3 & 5,56 \\
\hline $99-103$ & 5 & 9,26 \\
\hline $104-108$ & 6 & 11,11 \\
\hline $109-113$ & 14 & 25,93 \\
\hline $114-118$ & 11 & 20,37 \\
\hline $119-123$ & 10 & 18,51 \\
\hline $124-128$ & 5 & 9,26 \\
\hline Total & 54 & 100 \\
\hline
\end{tabular}

Based on the data in Table 4.3, it can be described the performance variable data of MTsN 3 (Islamic Junior High School 3) Simalungun that with mean (mean) 112.5 in the interval class 109 - 113, this means there are $25.93 \%$ of respondents in the class average score , $25.93 \%$ below the class average score and $48.14 \%$ above the class average score.

Testing the tendency of data for each study variable is the variable empowerment of subject teacher discussion $\left(\mathrm{X}_{1}\right)$, achievement motivation variable teacher MTsN 3 (Islamic Junior High School 3) Simalungun $\left(\mathrm{X}_{2}\right)$ and teacher teacher performance variables MTsN 3 (Islamic Junior High School 3) Simalungun (Y) used ideal score average and ideal standard deviation for each variable which is then categorized into 4 (four) categories, namely high, medium, less and low.

a. Test the tendency of MGMP empowerment variables

The results of testing the tendency of variable empowerment of subject teacher discussions $\left(\mathrm{X}_{1}\right)$ are illustrated in Table 4.4 as follows: 
Table 4.4 Level of Trend of MGMP Empowerment Variables $\left(\mathrm{X}_{1}\right)$

\begin{tabular}{|c|c|c|c|}
\hline Interval Score & Frequency & $\mathrm{f}_{\text {relative }}(\%)$ & Category \\
\hline$\geq 112$ & 42 & 77,78 & High \\
\hline $84-111$ & 12 & 22,22 & Medium \\
\hline $56-83$ & - & - & Less \\
\hline$\leq 55$ & - & - & Low \\
\hline Total & 54 & 100 & \\
\hline
\end{tabular}

Based on the data in Table 4.6 can be described for the variable empowerment of subject teacher discussion in the high category $77.78 \%$ and the moderate category at $22.22 \%$. Whereas for the less category and low category there is no. Thus it can be concluded that the empowerment of subject teacher discussion in this study tends to be high as evidenced by $77.78 \%$ of respondents in the high category.

b. Test the tendency of achievement motivation variables $\left(\mathrm{X}_{2}\right)$

The results of testing the tendency of achievement motivation variables of teachers in MTsN 3 (Islamic Junior High School 3) Simalungun $\left(\mathrm{X}_{2}\right)$ are illustrated in Table 4.5 as follows:

Table 4.5 Tendency Level of Achievement Motivation Variables $\left(\mathrm{X}_{2}\right)$

\begin{tabular}{|c|c|c|c|}
\hline Interval Score & Frequency & $\mathrm{f}_{\text {relative }}(\%)$ & Category \\
\hline$\geq 112$ & 42 & 77,78 & High \\
\hline $84-111$ & 12 & 22,22 & Medium \\
\hline $56-83$ & - & - & Less \\
\hline$\leq 55$ & - & - & Low \\
\hline Total & 50 & 100 & \\
\hline
\end{tabular}

Based on the data in Table 4.5 can be described for achievement motivation variable teachers MTsN 3 (Islamic Junior High School 3) Simalungun in the high category $77.78 \%$ and the moderate category of $22.22 \%$. Whereas for the less category and low category there is no. Thus it can be concluded that achievement motivation in this study tends to be high as evidenced by $77.78 \%$ of respondents in the high category.

c. Test the trend of teacher performance variables $(\mathrm{Y})$

The results of testing the trend of teacher teacher performance variables MTsN 3 (Islamic Junior High School 3) Simalungun (Y) are illustrated in Table 4.6 below: 
Table 4.6 Trends in Teacher Performance Variables (Y)

\begin{tabular}{|c|c|c|c|}
\hline Interval Score & Frequency & $\mathrm{f}_{\text {relative }}(\%)$ & Category \\
\hline$\geq 112$ & 29 & 53,70 & High \\
\hline $84-111$ & 25 & 46,30 & Medium \\
\hline $56-83$ & - & - & Less \\
\hline$\leq 55$ & - & - & Low \\
\hline Total & 50 & 100 & \\
\hline
\end{tabular}

Based on the data in Table 4.6 can be described for the variable performance of teacher teachers at MTsN 3 (Islamic Junior High School 3) Simalungun in the 53.70\% high category and the moderate category at $46.30 \%$. Whereas for the less category and low category there is no. Thus it can be concluded that teacher performance in this study tends to be high as evidenced by $53.70 \%$ of respondents in the high category.

Testing requirements analysis is intended as a requirement test to use correlation and regression analysis techniques before the data is analyzed. Requirements testing carried out is normality test, linearity test and independence test between independent variables.

The results of testing the normality of the data of this research variable are the variable empowerment of subject teacher discussion, achievement motivation of teachers in Simalungun Madrasah Tsanawiyah Negeri 3, and the performance variable of MTsN 3 (Islamic Junior High School 3) Simalungun.

This can be seen from the price of Liliefors observation (Lo), the calculation results of each variable indicate a value that is smaller than the value of the Liliefors table (Lt). Thus the data from the three research variables came from populations that were normally distributed, so that they met the requirements to be analyzed by correlation and regression. The summary of the results of the normality test of the research variables can be seen in Table 4.7.

Table 4.7 Summary of Analysis of Normality Tests

\begin{tabular}{|c|c|c|c|c|}
\hline No & Estimated Error & Lo & $\mathrm{L}_{\text {table }}(\alpha=0,05)$ & Information \\
\hline 1 & Y on $\mathrm{X}_{1}$ & 0,0820 & 0,1205 & Normal \\
\hline 2 & Y on $\mathrm{X}_{2}$ & 0,0991 & 0,1205 & Normal \\
\hline
\end{tabular}

Based on the table above it can be seen that the Liliefors observation value is smaller than the Liliefors table value, this shows the overall score of the research variable is normally distributed. For the variable error of empowering subject teacher discussion on the performance of teacher teachers in Simalungun Madrasah Tsanawiyah Negeri 3, the price of Lo (0.0991) $<$ Ltabel $(0.1205)$ was obtained, thus the variable of teacher subject discussion on the performance of MTsN 3 (Islamic Junior High School 3) Simalungun was normally distributed

For errors in the achievement motivation variable of Simalungun State 3 Madrasah Tsanawiyah Negeri 3 teacher performance variables, Simalungun Madrasah Tsanawiyah Negeri 3, the price of Lo $(0.0973)<\mathrm{L}_{\text {tabel }}(0.1205)$ was thus an error in the Simalungun 
Madrasah Tsanawiyah 3 teacher's performance variable teachers of Simalungun MTsN 3 (Islamic Junior High School 3) Simalungun are normally distributed.

The simple regression equation that is sought is a simple regression equation between the performance variables of Simalungun (3) teacher Madrasah Tsanawiyah Negeri 3 ( $\left.\mathrm{Y}_{1}\right)$, and teacher teacher performance variables MTsN 3 (Islamic Junior High School 3) Simalungun (Y) on teacher achievement motivation variables Simalungun $\left(\mathrm{X}_{2}\right)$ Madrasah Tsanawiyah Negeri $3\left(\mathrm{X}_{2}\right)$ with the equation model is $\hat{\mathrm{Y}}=\mathrm{a}+\mathrm{bX} 1$, and $\mathrm{b}=\mathrm{a}+\mathrm{bX} \mathrm{X}_{2}$.

\section{a. Test the linearity and significance of the regression variable $X_{1}$ with $Y$}

The results of calculation of variable linearity empowering subject teacher discussion $\left(\mathrm{X}_{1}\right)$ with teacher performance variables MTsN 3 (Islamic Junior High School 3) Simalungun (Y) obtained a simple regression equation $\hat{\mathrm{Y}}=72.38+0.35 \mathrm{X}_{1}$. The summary of the calculation results can be seen in Table 4.8. as follows:

Table 4.8 Anava Summary Linearity Test Between $\mathrm{X}_{1}$ and $\mathrm{Y}$

\begin{tabular}{|c|c|c|c|c|c|}
\hline & $\mathrm{JK}$ & $\mathrm{DK}$ & $\mathrm{RJK}$ & $\mathrm{F}_{\text {hitung }}$ & $\mathrm{F}_{\text {table }} \alpha=0,05$ \\
\hline Total & 692218 & 54 & - & - & - \\
\hline Regresi (a) & 688170,67 & 1 & 688170,67 & & \\
Regresi (b/a) & 608,76 & 1 & 608,76 & 9,206 & 4,026 \\
Residue & 3438,57 & 52 & 66,12 & & \\
\hline Tuna Suitable & 2307,12 & 27 & 85,44 & 1,888 & 1,946 \\
Error & 1131,45 & 25 & 45,25 & & \\
\hline
\end{tabular}

Based on the table above, it can be seen that the regression count is obtained 9,206 while the price of Ftable with the numerator 1 and the denominator 52 at the significance level $\alpha=$ 0.05 is 4.026. It turns out that the price of the regression count $(9,206)$ is greater than the price of Ftable $(4,026)$, so it can be concluded that the regression coefficient $\mathrm{Y}$ over $\mathrm{X}_{2}$ means at the significance level $\alpha=0.05$.

Furthermore, it is known that the price of $F$ tuna matches the calculation results obtained at 1.888 while the price of Ftable with dk numerator 27 and the denominator 25 at the significance level $\alpha=0.05$ is 1.946 . Because the price of $F$ tuna matched count 1.888 is smaller than the value of $F_{\text {table }}$ 1.946. This shows the variable of giving the subject teacher discussion $\left(\mathrm{X}_{1}\right)$ to the performance variable of the teacher of Simalungun State 3 Madrasah Tsanawiyah (Y) with the regression line equation $\hat{\mathrm{Y}}=72.38+0.35 \mathrm{X}_{1}$ is linear.

$\mathrm{Y}$ over $\mathrm{X}_{2}$ regression mean calculation in Table 4.8 shows the price of $\mathrm{Fh}>\mathrm{Ft}$. This means that the regression direction coefficient $\mathrm{Y}$ on $\mathrm{X}_{2}$ is significant at the level of $\alpha=0.05$. Thus the regression equation $\hat{Y}=72.38+0.35 \mathrm{X}_{1}$ can be accounted for to draw conclusions about the relationship between empowerment of subject teacher discussions with the performance of teachers at Simalungun State Madrasah Tsanawiyah 3. In other words, an increase in one score of empowerment of subject teacher discussions will increase by 0.35 scores on teacher performance variables. 


\section{b. Test the linearity and regression significance of $X_{2}$ variables with $Y$}

The results of the linearity calculation of achievement motivation teachers of MTsN 3 (Islamic Junior High School 3) Simalungun $\left(\mathrm{X}_{2}\right)$ with teacher performance variables MTsN 3 (Islamic Junior High School 3) Simalungun (Y) obtained a simple regression equation $\hat{\mathrm{Y}}=$ $69.48+0.37 \mathrm{X} 2$.

A summary of the results of the calculation of linearity testing and its significance can be seen in Table 4.9.

Table 4.9 Anava Summary Linearity Test Between $\mathrm{X}_{2}$ and $\mathrm{Y}$

\begin{tabular}{|c|c|c|c|c|c|}
\hline & JK & DK & RJK & $F_{\text {count }}$ & $F_{\text {table }} \alpha=0,05$ \\
\hline Total & 692218 & 54 & - & - & - \\
\hline Regresi (a) & 688170,67 & 1 & 688170,67 & & \\
Regresi (b/a) & 462,21 & 1 & 462,21 & 6,704 & 4,026 \\
Residue & 3585,12 & 52 & 68,94 & & \\
\hline Tuna Suitable & 1412,98 & 21 & 67,28 & 0,961 & 1,920 \\
Error & 2169,14 & 31 & 69,97 & & \\
\hline
\end{tabular}

Based on the table above it can be seen that the regression count is obtained at 6.704 while the price of Ftable with the numerator 1 and the denominator 52 at the significance level $\alpha=0.05$ is 4.026 . It turns out that the price of the regression count (6.704) is greater than the price of $\mathrm{F}_{\text {table }}(4,026)$, so it can be concluded that the regression coefficient $\mathrm{Y}$ on $\mathrm{X}_{2}$ means at the significance level $\alpha=0.05$.

Furthermore, it is known that the price of $\mathrm{F}$ tuna matches the calculation results obtained at 0.961 while the price of Ftable with the numerator 21 and the denominator 31 at the significance level $\alpha=0.05$ is 1.920 . Because the price of $F$ tuna matched count is 0.961 smaller than the value of $\mathrm{F}_{\text {table }} 1.920$.

This shows the achievement motivation variable of the teacher of MTsN 3 (Islamic Junior High School 3) Simalungun $\left(\mathrm{X}_{2}\right)$ towards the performance variable of the teacher of Simalungun State 3 Madrasah Tsanawiyah $(\mathrm{Y})$ with the regression line equation $\hat{Y}=69.48+$ $0.37 \mathrm{X}_{2}$ is linear.

The calculation of regression significance $\mathrm{Y}$ on $\mathrm{X}_{2}$ in Table 4.9 shows the price of $\mathrm{Fh}>$ Ft. This means that the regression direction coefficient $\mathrm{Y}$ on $\mathrm{X}_{2}$ is significant at the level of $\alpha$ $=0.05$. Thus the regression equation $\hat{Y}=69.48+0.37 \mathrm{X}_{2}$ can be accounted for to draw conclusions regarding the relationship between achievement motivation teachers of Simalungun Madrasah Tsanawiyah Negeri 3 and the performance of teachers in MTsN 3 (Islamic Junior High School 3) Simalungun. In other words an increase in one score of achievement motivation will increase by 0.37 scores on the teacher performance variable.

Before conducting correlation and regression analysis, it is necessary to know the relationship between the variables of empowerment of subject teacher discussion $(X \neg 1)$ and achievement motivation teachers of MTsN 3 (Islamic Junior High School 3) Simalungun $\left(\mathrm{X}_{2}\right)$ are truly independent or do not have correlation with each other so independence testing needs to be done between independent variables.

The results of testing analysis between the variables of empowerment of subject teacher discussion $(X \neg 1)$ and achievement motivation variables of MTsN 3 (Islamic Junior High 
School 3) Simalungun $\left(\mathrm{X}_{2}\right)$ teachers have a correlation of 0.163 . The summary of the calculation results can be seen in Table 4.10 as follows:

Table 4.10 Summary of Independence Test Between Variables $\mathrm{X}_{1}$ With $\mathrm{X}_{2}$

\begin{tabular}{|c|c|c|c|c|}
\hline Correlation & $\begin{array}{c}\text { Correlation } \\
\text { coefficient }(r)\end{array}$ & $\begin{array}{c}\text { Determinant } \\
\text { coefficient }\left(\mathrm{r}^{2}\right)\end{array}$ & $\mathrm{T}_{\text {count }}$ & $\begin{array}{c}\mathrm{T}_{\text {table }} \\
(\alpha=0,05)\end{array}$ \\
\hline $\mathrm{rX}_{1} \mathrm{X}_{2}$ & 0,163 & 0,026 & 1,18 & 1,674 \\
\hline
\end{tabular}

Based on the table above shows that the correlation coefficient between the variable empowerment of subject teacher discussion (X1) and achievement motivation variables teachers MTsN 3 (Islamic Junior High School 3) Simalungun (X2) is 0.163 with a coefficient of determination ( $\mathrm{r} 2$ ) of 0.026 .

Furthermore, through the $t$ test that has been done, it turns out that tcount $=1.18$ obtained while the ttable $=1.674$. Therefore, tcount $(1.18)<$ ttable (1.674), this indicates that the two independent variables do not have a meaningful relationship so the two independent variables are independent variables.

Based on the test of the tendency of variable data empowerment of subject teacher discussion shows the categories of high, medium, less and low as follows: high category with a range of scores $\geq 112$ is $77.78 \%$ and the medium category with a score range of 84 to 111 is $22.22 \%$. Based on the tendency of the data indicates that overall the respondents of the study were teachers of MTsN 3 (Islamic Junior High School 3) Simalungun, the majority had a tendency in empowering high-category subject teacher consultations.

Furthermore, if we look at the indicators that form the empowerment of subject teacher consultations, namely aspects: (1) compiling the subject teacher discussion program, (2) motivating the subject matter teachers to attend subject teacher meetings regularly; (3) increasing teacher professionalism, (4) developing clinical academic supervision service programs, (5) developing learning tools, (6) seeking scientific meetings, (7) formulating varied learning models, and (8) reporting on results of activities, then aspects of teacher motivation in participating in routine teacher subject discussion activities and increasing teacher professionalism still appear weak. Although overall the category of tendency for empowerment of subject teacher discussion is high, however, there are quite high percentages in the medium category, namely $22.22 \%$.

Based on the trend test data of achievement motivation variable of Simalungun MTsN 3 (Islamic Junior High School 3) Simalungun shows the following categories of high, medium, less and low: high category with a range of scores $\geq 112$ is $77.78 \%$ and medium category with a score range 84 to 111 is $22,22 \%$. Based on the tendency of these data indicate that overall the respondents of the study in this case were teachers of MTsN 3 (Islamic Junior High School 3) Simalungun, the majority had a tendency towards achievement motivation to be a high category.

Based on the trend test data, the teacher performance variable of Simalungun Madrasah Tsanawiyah Negeri 3 shows the following categories: high, medium, less and low: high category with a score of $\geq 112$ is $53.70 \%$ and medium category with a score of 84 to 1119 is $46.30 \%$. Based on the tendency of the data indicates that overall the majority of study 
respondents had a tendency towards the performance of teachers in MTsN 3 (Islamic Junior High School 3) Simalungun was a high category. However, the percentage of teacher performance in the medium category is quite large at $46.30 \%$.

Furthermore, if we pay attention to the indicators that form the performance of teachers in Simalungun State Madrasah Tsanawiyah 3, namely: ((1) arranging learning plans, (2) implementing learning, and (3) evaluating learning outcomes, the aspects of implementing learning specifically apply various models or learning strategies Variables that still look weak, this fact shows that the performance of teachers in MTsN 3 (Islamic Junior High School 3) Simalungun Weak is dominated by weaknesses and shortcomings in the aspects of implementing learning.

\section{Conclusion}

There is a positive and significant relationship between MGMP empowerment and teacher performance. It means that the higher and positive the MGMP empowerment, the higher and positive the teacher's performance by providing an effective contribution of $13.82 \%$. This can be interpreted that the variation that occurs in the MGMP empowerment variable of $13.82 \%$ can be predicted in improving teacher performance. There is a positive and significant relationship between achievement motivation and teacher performance. It means that the higher and positive achievement motivation is the higher and positive the teacher's performance by making an effective contribution of $8.74 \%$. This can be interpreted that the variation that occurred in the achievement motivation of $8.74 \%$ can be predicted in improving teacher performance. There is a positive and significant relationship together between MGMP empowerment and achievement motivation with teacher performance. It means that the higher and positive MGMP empowerment and achievement motivation, the higher and positive the teacher's performance by making an effective contribution of $22.60 \%$. This means that $22.60 \%$ of the variations that occur in teacher performance can be predicted by the two independent variables.

\section{References}

Achmad, A. Memberdayakan MGMP, Sebuah Keniscayaan. www. Google, 2004.

Arifin, Muh. Husen Pengaruh Gaya Kepemimpinan Kepala Sekolah, Motivasi Berprestasi Dan Iklim Sekolah Terhadap Kinerja Guru Di Man 2 Kabupaten Probolinggo, Journal: Pendidikan Ilmu Pengetahuan Sosial Indonesia Volume 3 number 12018.

Departemen Pendidikan Nasional RI. Rambu-Rambu Pengembangan Kegiatan KKG dan MGMP. Jakarta: Depdiknas Dirjen PMPTK, 2009.

Firman. Peranan MGMP Dalam Meningkatkan Kinerja Guru Mata Pelajaran Pendidikan Agama Islam SMA di Kota Balikpapan. Journal: Sains Terapan No. 1 Vol. 2. 2015.

Haryanti, Titik. Pengaruh Motivasi Berprestasi Terhadap Kinerja Guru Di SMK Tunas Pemuda. Journal: Research and Development Journal Of Education Vol. 4 No. 1 October 2017

Hidayat, Yusuf. Pengaruh Pelaksanaan Kebijakan Musyawarah Guru Mata Pelajaran Bahasa Inggris terhadap Manajemen Pembelajaran dalam Mewujudkan Kinerja Guru. Journal: Publik Vol. 11; No. 02; 2017; 279-290 
Hendrati, Fabiola. Hubungan Motivasi Berprestasi dan Harga Diri dengan Kinerja Guru SD di Malang. Jurnal Psikologi Tabularasa Volume 9, No.2, October 2014.

Ivancevch, at el. Perilaku dan Manajemen organisasi. Edisi Ketujuh, Alih Bahasa: Gina Gania. Jakarta: Erlangga, 2007.

Jurotun, Samsudi, dan Prihatin, Titi. Model Supervisi Akademik Terpadu Berbasis Pemberdayaan Mgmp Untuk Meningkatkan Kompetensi Pedagogik Guru Matematika. Journal: Penelitian Tindakan Sekolah dan Kepengawasan Vol. 2, No. 1, June 2015.

Kamars, Daniel. Administrasi Pendidikan Teori dan Praktek. Edisi Kedua. Padang: Universitas Putra Indonesia Press, 2005.

Khairunisa. Pengaruh Motivasi Berprestasi Dan Kepuasan Kerja Terhadap Kinerja Guru Sdn Di Kecamatan Banjarmasin Tengah. Journal: Paradigma, Volume 10, Number 2, July 2015.

Luthans, F. Perilaku Organisasi. Edisi Kesepuluh. Alih Bahasa: Vivin Andika Yuwono, at el. Yogyakarta: Andi Offset, 2008.

Mas'udi. Pengaruh Komitmen Dan Motivasi Berprestasi Terhadap Kinerja Guru SMA Negeri 56 Jakarta. Journal: Mix, Volume IV, No. 2, June 2014.

Mujahidin. Pengaruh Kompetensi Pedagogik dan Motivasi Berprestasi Terhadap Kinerja Guru di SMPN 8 Sekayu Musi Banyuasin. Journal: Belajea Pendidikan Islam, Vol. 1, No. 02, 2016.

Pace, R, W. and Faules, D, F. Komunikasi Organisasi Strategi Meningkatkan Kinerja Perusahaan. Bandung: Remaja Rosdakarya, 2006.

Robbins, Stephen. P. Perilaku Organisasi, Edisi Kesepuluh Alih Bahasa: Benyamin Molan. Indonesia: Macanan Jaya Cemerlang, 2007.

Sagala, Syaiful. Manajemen Berbasis Sekolah dan Masyarakat Strategi Memenangkan Persaingan Mutu. Jakarta: Nimas Multima, 2006. 2007.

Manajemen Strategik Peningkatan Mutu Pendidikan. Bandung: Alfabeta,

Saragih, Mandra dan Dewi, Ratna Sari Efektifitas Musyawarah Guru Mata Pelajaran Untuk Meningkatkan Kompetensi Guru Bahasa Inggris Di Kota Binjai. Journal: Tarbiyah, vast

Saud, Udin. Saefuddin. Pengembangan Profesi Guru. Bandung: Alfabeta, 2009.

Somantri, A. and Muhidin, S. A. Aplikasi Statistik Dalam Penelitian. Bandung: Pustaka Setia, 2006.

Sudjana. Metode Statistika. Bandung: Tarsito, 2000.

Sugiyono. Metode Penelitian Pendidikan. Bandung: Alfabeta, 2007.

Supraswati, Ida. Hubungan Antara Motivasi Berprestasi Dengan Kinerja Guru Dalam Pembelajaran Sdn Gugus Silawe Kajoran Magelang. Journal: Pendidikan Sekolah Dasar Edisi Ke-IV Tahun 2016

Syafarudin. Efektifitas Kebijakan Pendidikan. Jakarta: Rineka Cipta, 2008.

Thoha, M. Perilaku Organisasi Konsep Dasar dan Aplikasinya. Jakarta: Raja Grafindo Persada, 2008.

Tjiptono, F. and Diana, A. 2004. Total Quality Management. Yogyakarta: Andi Offset 
Undang-Undang RI Nomor 20 Tahun 2003 tentang Sistem Pendidikan Nasional, Jakarta: Bumi Aksara.

Undang-Undang RI Nomor 14 Tahun 2005 tentang Guru dan Dosen, Jakarta: Bumi Aksara.

Usman, H. and Akbar, P.S. Pengantar Statistik. Edisi Kedua, Jakarta: Bumi Aksara, 2008.

Usman, H. Manajemen Teori Praktik dan Riset Pendidikan. Edisi Kedua, Jakarta: Bumi Aksara, 2008.

Wardana, Dendik Surya. Motivasi Berprestasi Dengan Kinerja Guru Yang Sudah Disertifikasi. Journal: Ilmiah Ilmu Psikologi Vol. 01, No.01, January 2013.

Wibowo. Manajemen Kinerja, Jakarta: Raja Grafindo Perkasa, 2007.

Winardi, J. Motivasi dan Pemotivasian Dalam Manajemen. Jakarta: Raja Grafindo Persada, 2007

Yuniarsih, T. dan Suwatno. Manajemen Sumber Daya Manusia. Teori, Aplikasi dan Isu Penelitian. Bandung: Alfabeta, 2008.

Yunusshofa. 2008. Keefektifan MGMP PAI SMP Terhadap Peningkatan Profesionalisme Guru PAI Kabupaten Cianjur. (Online), (http://Yunusshofa .blogspot. com/2008/05/keefektifan-mgmp-pai-dalam-meningkatkan. html) 